\title{
Acid matrix production from treated natural vermiculite-hydrobiotite
}

\author{
N.P.Alexandre ${ }^{1 *}$, G. S. Oliveira ${ }^{1}$, C.R.F.Alves ${ }^{1}$, L. D. da Silva ${ }^{1}$ \\ ${ }^{1}$ Universidade Federal do Ceará, Departamento de Química Orgânica e Inorgânica, Fortaleza, CE, Brazil
}

\begin{abstract}
Given the potential of acid-activated clays in adsorptive and catalytic processes, several studies focusing on acid matrices have grown over the years, making it possible to study vermiculite, a mineral composed of a type 2:1 unit cell with tetrahedral and octahedral sheets. Therefore, this work aimed to study vermiculite treated with acids for the production of matrices. In this work, the treatment of natural vermiculite-hydrobiotite, with nitric acid in concentrations of $0.25,0.50,0.75$, and 1 mol. $\mathrm{L}^{-1}$, followed by the dealumination process with sulfuric acid $25 \% \mathrm{v} / \mathrm{v}$, aiming the production of acid matrices for applications as support for biocatalysts, chemical adsorbents, among others. The produced materials were characterized using different techniques, including X-ray fluorescence spectroscopy, X-ray diffraction, scanning electron microscopy, Fourier transform infrared spectroscopy, thermogravimetric analysis, and isotherm adsorption using the BET method. The results showed that after acid leaching the vermiculite showed a high $\mathrm{SiO}_{2}$ content, high Brønsted and Lewis surface acidity, good adsorption/desorption performance, and significant growth of the specific surface area, qualifying the vermiculite as a promising material for future applications in catalytic and biocatalytic processes. The acid concentration had a considerable influence on the compositional and textural modification of vermiculite-hydrobiotite.
\end{abstract}

Keywords: vermiculite, nitric acid, leaching, matrices, catalytic.

\section{INTRODUCTION}

The search for low-cost materials used in the catalysis and adsorption processes has been growing in recent years, stimulating the study of clay minerals for this purpose [14]. Clay minerals are abundant in nature and are susceptible to chemical changes in their interlayer structures, in which ions, atoms, or molecules are inserted, giving them countless applications [5]. Some of the classes of clay minerals stand out for several characteristics, such as the high cation exchange capacity (CTC), expansiveness, and plasticity [6]. Vermiculite-hydrobiotite is a mineral clay that has been intensively studied considering its applications in several areas, for instance, catalytic processes, agriculture, and adsorbent for gases and pollutants, e.g. metals and organic species, mainly due to its high cation exchange capacity (CTC) and expansion [7-9]. They are phyllosilicates composed of a type 2:1 structure (T-O-T), which has continuous sheets of silicon or aluminum tetrahedra $(\mathrm{T})$ and octahedral sheets (O) of aluminum (magnesium or iron), in addition to hydroxyls and cations [10-12]. The exchangeable cations present mainly in the interlayered space of the vermiculite-hydrobiotite structure, which in general are $\mathrm{Na}^{+}, \mathrm{Mg}^{2+}$, and $\mathrm{Ca}^{2+}$, counteract the negative surface charges resulted from the high degree of isomorphic substitution of $\mathrm{Si}^{4+}$ by $\mathrm{Al}^{3+}$ and/or $\mathrm{Fe}^{3+}$ in the tetrahedral and $\mathrm{Mg}^{2+}$ by $\mathrm{Al}^{3+}, \mathrm{Fe}^{2+}$, and $\mathrm{Fe}^{3+}$ in the octahedral layers [13, 14]. Despite having remarkable properties, some processes that alter its structure and/or composition such as calcination and acidification, have been carried out to obtain solids with high efficiency in catalytic and adsorptive processes [15, 16]. Treatment with mineral acids, called acid activation or leaching, considerably increases the adsorptive capacity and the catalytic activity of clays, mainly as a result of the increase in their specific surface areas and the increase in reactive acid sites [17, 18].

Acid leaching is carried out by mixing the clay with acid under controlled operating conditions that promote the replacement of exchangeable cations with hydroxonium cations $\left(\mathrm{H}_{3} \mathrm{O}^{+}\right)$and the leaching in the octahedral leaves of some elements such as $\mathrm{Mg}^{2+}, \mathrm{Fe}^{2+}, \mathrm{Fe}^{3+}$, and $\mathrm{Al}^{3+}[19,20]$. The composition of the octahedral leaves of vermiculite substantially affects its stability to acid attack; trioctahedral leaves (composed of $\mathrm{Mg}^{2+}$ or $\mathrm{Fe}^{2+}$ ) dissolve more quickly than the dioctahedral leaves (composed only of $\mathrm{Al}^{3+}$ ) [21]. The occurrence of iron in the mineral is also important, as it determines the surface area achieved after acid treatment. The final product is solid support with high $\mathrm{SiO}_{2}$ content, with a high specific surface area, and Brønsted and Lewis surface acidity [22]. Acid-activated clays are generally used as adsorbents in vegetable, animal, wine, and beer industries, and are also used as catalysts in several organic reactions [23]. In this study, the treatment of natural vermiculite with nitric acid in different treatments, as well as with sulfuric acid 25\% v/v in the production of Brønsted and Lewis acid sites were investigated in order to prepare acid matrices for future applications as catalytic supports and chemical adsorbents.

\section{MATERIALS AND METHODS}

The vermiculite used was supplied by Policlay Nanotech 
located in the city of Fortaleza-CE, Brazil. The synthesis of the materials was carried out following two steps: i) treatment with nitric acid $\left(\mathrm{HNO}_{3}\right.$, Vetec, $\left.65 \%\right)$; and ii) dealumination with sulfuric acid $\left(\mathrm{H}_{2} \mathrm{SO}_{4}\right.$, R.G., Synth, $\left.98 \%\right)$ at $25 \%$ v.v ${ }^{-1}$. In short, $45 \mathrm{~g}$ of vermiculite were ground and sieved with a $100 \mu \mathrm{m}$ mesh sieve, which was named natural vermiculite (VN0). In a round bottom flask, $10 \mathrm{~g}$ of vermiculite and 100 $\mathrm{mL}$ of $\mathrm{HNO}_{3}$ were added. The mixture was placed in a reflux system with constant stirring for $4 \mathrm{~h}$ at $95^{\circ} \mathrm{C}$, according to the methodology used by Rey-Perez-Caballero and Poncelet [21]. Then, the solid was washed with deionized water to a $\mathrm{pH} \geq 5$ and then dried overnight in an oven at $120{ }^{\circ} \mathrm{C}$. Acid activation was carried out at $\mathrm{HNO}_{3}$ concentrations of $0.25,0.5,0.75$, and $1.0 \mathrm{~mol} . \mathrm{L}^{-1}$ named respectively as VN1, $\mathrm{VN} 2, \mathrm{VN} 3$, and VN4. Then, the dealumination process was carried out, with a reaction mixture of $5 \mathrm{~g}$ of each activated vermiculite sample and $100 \mathrm{~mL}$ of $25 \% \mathrm{H}_{2} \mathrm{SO}_{4} \mathrm{v} \cdot \mathrm{v}^{-1}$ per gram of clay, which was subjected to agitation and heating at $80{ }^{\circ} \mathrm{C}$ under reflux for $2 \mathrm{~h}$. Then, the precipitate obtained was washed with deionized water until constant $\mathrm{pH}$ and centrifuged at $4000 \mathrm{rpm}$ for $5 \mathrm{~min}$. The treated material was oven-dried at $120^{\circ} \mathrm{C}$ for $12 \mathrm{~h}$.

Pyridine adsorption assay: the study of Lewis and Brønsted-Lowry acidity of acid-treated and dealuminized vermiculite was carried out using pyridine as a probe molecule, through absorption spectra in the infrared region of samples in the form of pressed tablets at 10 ton. The tablets were initially left under vacuum, followed by exposure to reagent pyridine $\left(\mathrm{C}_{5} \mathrm{H}_{5} \mathrm{~N}\right.$, ACS reagent, Sigma-Aldrich, $\geq 99 \%$ ) at room temperature for $1 \mathrm{~h}$. Then, the excess of the reagent was eliminated by submitting the system to vacuum again for another $1 \mathrm{~h}$. The quantification of the acid groups of Brønsted (Py-B, $\left.1545 \mathrm{~cm}^{-1}\right)$ and Lewis $\left(\mathrm{Py}-\mathrm{L}, 1440 \mathrm{~cm}^{-1}\right)$ was determined according to [21]:

$$
\mathrm{q}_{\mathrm{B}, \mathrm{L}}=\pi \mathrm{A} \cdot \mathrm{D}^{2}\left(4 \mathrm{w} \cdot \varepsilon_{\mathrm{B}, \mathrm{L}}\right)^{-1}
$$

where $\mathrm{A}$ is the integrated band area (u.m.a) and $\varepsilon_{\mathrm{B}, \mathrm{L}}$ the molar extinction coefficient $\left(\mu \mathrm{mol} . \mathrm{g}^{-1}\right)$.

Characterization: the structural and spectroscopic properties of natural vermiculite and vermiculite leached with nitric acid at concentrations of $0.25,0.5,0.75$, and $1.0 \mathrm{~mol} . \mathrm{L}^{-1}$ were characterized. $X$-ray diffraction $(X R D)$ : for XRD analysis, the samples obtained were analyzed using an X-ray powder diffractometer (X-Pert, Panalytical) with Bragg-Brentano geometry. The XRD patterns were collected in continuous mode with a scanning speed of $0.5^{\circ} \cdot \mathrm{min}^{-1}$ in the range of $5-80^{\circ}(2 \theta)$. CoK $\alpha$ radiation was used, obtained with a tube operating at $40 \mathrm{kV}$ and $40 \mathrm{~mA}$. Before XRD measurements, powder samples were sieved through a $75 \mu \mathrm{m}$ screen (200 mesh). X-ray fluorescence $(X R F)$ spectroscopy: the chemical composition of the treated vermiculite was determined using the semi-quantitative XRF technique (ZSX Mini-II, Rigaku). Fourier transform infrared (FTIR) spectroscopy: FTIR spectra were obtained using a spectrometer (FT-IR Spectrum, Perkin-Elmer) using the $\mathrm{KBr}$ tablet technique, in a $2.5 \%$ mass ratio. The scan was in a wavelength range from 1300 to $1800 \mathrm{~cm}^{-1}$. Scanning electron microscopy (SEM): SEM images were obtained using a microscope (Quanta 450 FEG, FEI). The samples were prepared on double-sided carbon tape on aluminum supports, being covered with gold in an argon atmosphere under low pressure. Thermogravimetric analyzes $(T G)$ were performed with a thermal analyzer (TGA-50H, Shimadzu) with a nitrogen flow of $50 \mathrm{~cm}^{3} / \mathrm{min}$. The thermogravimetric curves were obtained in a nitrogen atmosphere using a heating rate of $10{ }^{\circ} \mathrm{C} \cdot \mathrm{min}^{-1}$ and a temperature range of 0-800 ${ }^{\circ} \mathrm{C}$. The textural characterizations of the samples were obtained in an adsorptometer (ASAP 2020, Micromeritics). The samples were subjected to degassing at $300{ }^{\circ} \mathrm{C}$ for 24 h. From the $\mathrm{N}_{2}$ isotherms obtained at $77 \mathrm{~K}$, the surface area was calculated according to the BET model and the pore diameter according to the $\mathrm{BJH}$ model.

\section{RESULTS AND DISCUSSION}

$X R F$ : the results of the X-ray fluorescence analysis of the natural and leached hydrobiotite vermiculite, in different types of acid, are shown in Table I. The natural sample had a high content of $\mathrm{Fe}_{2} \mathrm{O}_{3}(25.11 \%)$. This result may be associated with the fact that vermiculite, in general, presents a great variation in its chemical composition. This variation occurs due to differences in its mineralization, the presence in soils under hot and humid climates, among other factors [24]. The main constituent oxides of the clay are $\mathrm{SiO}_{2}, \mathrm{Al}_{2} \mathrm{O}_{3}$, $\mathrm{MgO}$, and $\mathrm{Fe}_{2} \mathrm{O}_{3}$ [24]. Comparing the chemical composition of the natural vermiculite-hydrobiotite (VNO) sample and the samples leached with 0.25 to $1.0 \mathrm{~mol} \cdot \mathrm{L}^{-1}$ acid (VN1 to VN4), it was seen that as the acid concentration increased a decrease in contents of the oxides of $\mathrm{Fe}, \mathrm{Al}, \mathrm{Mg}$, and $\mathrm{K}$ occurred concomitantly, as expected, with a progressive increase in the silica content, resulted from the replacement of these metals by hydronium ions $\left(\mathrm{H}_{3} \mathrm{O}^{+}\right)$in the interlayer space and in the octahedral leaves $[3,25,26]$. A significant increase in the silica content was observed after treatment with $1.0 \mathrm{~mol}^{\mathrm{L}} \mathrm{L}^{-1} \mathrm{HNO}_{3}$ $\left(\mathrm{SiO}_{2} / \mathrm{Al}_{2} \mathrm{O}_{3}\right.$ ratio=11.23), due to the greater dissolution of these elements, while the tetrahedral leaves form amorphous silica gel, insoluble in acid solution [27]. The acid attack resulted in the regeneration of ion-exchange properties, where it was possible to observe a decrease in the $\mathrm{K}_{2} \mathrm{O}$ content. This fact may occur due to the exchange of cations present in the structure for $\mathrm{H}_{3} \mathrm{O}^{+}$. The dissolution of metals in the vermiculite structure after acid treatment promoted the removal of $\mathrm{Al}^{3+}$ cations from the tetrahedral leaves, generating acidity in the clays. The number of substitutions by $\mathrm{Mg}$ or $\mathrm{Fe}$ in the octahedral sheets of clay mineral promoted the dissolution of these layers and the formation of a silica phase [3]. In addition, the iron composition in the interlayered charges in the hydrobiotite vermiculite under study may be present according to the oxidation of $\mathrm{Fe}^{2+}$ to $\mathrm{Fe}^{3+}$. Such oxidation would increase the positive octahedral charge by an amount equivalent to the amount of oxidized bivalent iron and result in an equivalent decrease in the negative layer unit and positive interlayer charges [25]. 
Table I - Results of XRF analysis of natural vermiculitehydrobiotite (VN0) and samples leached with $\mathrm{HNO}_{3}$ at 0.25 mol. $\mathrm{L}^{-1}$ (VN1), $0.50 \mathrm{~mol} . \mathrm{L}^{-1}(\mathrm{VN} 2), 0.75 \mathrm{~mol} . \mathrm{L}^{-1}(\mathrm{VN} 3)$, and 1.0 mol. $\mathrm{L}^{-1}(\mathrm{VN} 4)$.

\begin{tabular}{cccccc}
\hline $\begin{array}{c}\text { Oxide } \\
(\%)\end{array}$ & $\mathrm{VN} 0$ & $\mathrm{VN} 1$ & $\mathrm{VN} 2$ & $\mathrm{VN} 3$ & $\mathrm{VN} 4$ \\
\hline $\mathrm{SiO}_{2}$ & 41.25 & 44.15 & 48.66 & 50.91 & 55.49 \\
$\mathrm{Al}_{2} \mathrm{O}_{3}$ & 7.20 & 6.87 & 6.84 & 5.30 & 4.94 \\
$\mathrm{Fe}_{2} \mathrm{O}_{3}$ & 25.11 & 23.15 & 21.07 & 21.37 & 20.69 \\
$\mathrm{MgO}$ & 13.00 & 13.15 & 11.66 & 10.56 & 8.38 \\
$\mathrm{CaO}$ & 5.41 & 6.77 & 4.72 & 5.08 & 4.07 \\
$\mathrm{~K}_{2} \mathrm{O}$ & 4.75 & 2.36 & 2.73 & 2.96 & 2.64 \\
$\mathrm{TiO}_{2}$ & 1.94 & 2.12 & 2.61 & 2.80 & 2.96 \\
$\mathrm{Cr}_{2} \mathrm{O}_{3}$ & 0.82 & 0.80 & 0.64 & 0.60 & 0.44 \\
$\mathrm{NiO}$ & 0.52 & 0.62 & 0.64 & 0.49 & 0.24 \\
\hline
\end{tabular}

$X R D$ : the X-ray diffraction patterns of natural vermiculite and vermiculite leached with nitric acid in different concentrations are shown in Fig. 1. The XRD pattern of natural vermiculite (VNO) showed the presence of a crystalline material with the main peak at $2 \theta=7.125^{\circ}$ [plane (002)] referring to the mineral vermiculite and the second peak of lesser intensity in the position $2 \theta=8.197^{\circ}$ related to the interstratified hydrobiotite phase $[25,28]$. The vermiculite from Paraíba-Brazil is composed of interstratified mixed layers of vermiculite with other mineralogical phases such as talc, hydrobiotite, biotite, and phlogopite. The XRD patterns shown in Fig. 1 show a continuous decrease in the crystallinity of the reflected natural sample and a progressive decrease in the intensity of the main reflection of the vermiculite and the interstratified hydrobiotite phase. Despite the aforementioned data, changes only in the

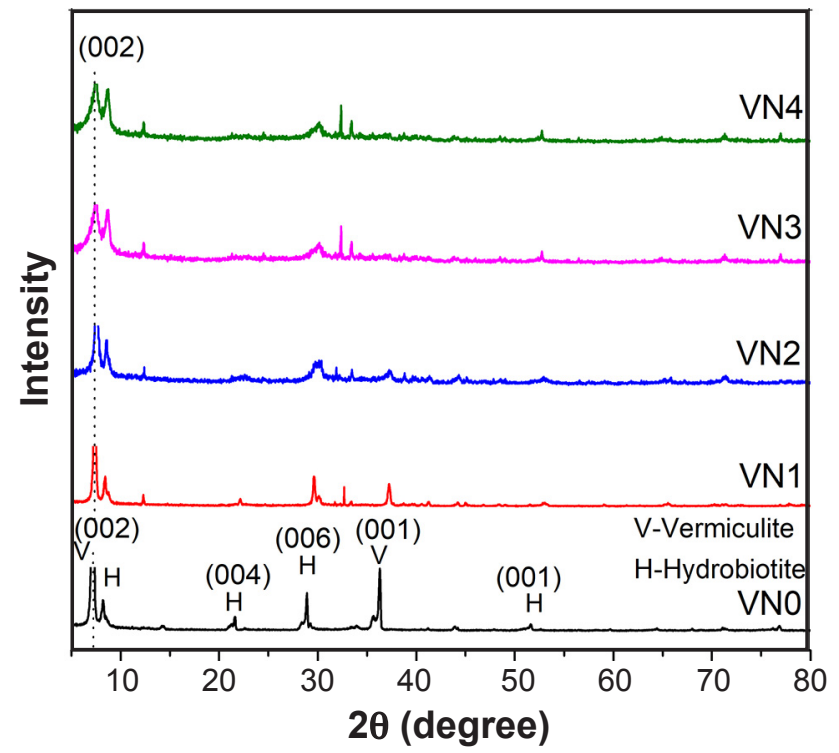

Figure 1: X-ray diffractogram of natural vermiculite-hydrobiotite (VN0) and samples leached with $\mathrm{HNO}_{3}$ (VN1-VN4). vermiculite peaks were taken into account, given the low amount of hydrobiotite (19\% in mass) and the limitation of the Rietveld method to identify changes in the interstratified clays. At the end of the treatment, there was a material that presented a delaminated and partially amorphized structure, since the main reflection peaks of the main constituents of vermiculite-hydrobiotite still appeared in the patterns, however, as already shown in Table I, with high silica content in the amorphous state. Furthermore, a small displacement of the peaks is observed after acid treatment with high concentrations of $\mathrm{HNO}_{3}$, as in the sample VN3. This occurred due to morphological changes in the crystalline structure of vermiculite-hydrobiotite, in the replacement of intercalating cations by hydronium ions $\left(\mathrm{H}_{3} \mathrm{O}^{+}\right)$, causing the displacement of the crystalline planes [16, 29].

FTIR: the analysis of the acidic properties of the materials produced was performed through absorption spectroscopy in the infrared region using pyridine as a molecule that quantifies the acidity characterizing it as Brønsted and Lewis. To distinguish Brønsted and Lewis acidity, the positions of the vibrational modes of pyridine were observed in a short order of reach [30]. The acidic surface observed in the vermiculite after acidic treatment is directly related to the presence of $\mathrm{SiOH}$ or $\mathrm{AlOH}$ groups in its composition. This acidic character refers to the Brønsted sites associated with proton donation in the dehydroxylation of the lamellae and to the Lewis sites, electron pair receptors, which can be attributed to metal oxides [31]. FTIR analysis of natural vermiculite did not show bands referring to Lewis acids and Brønsted

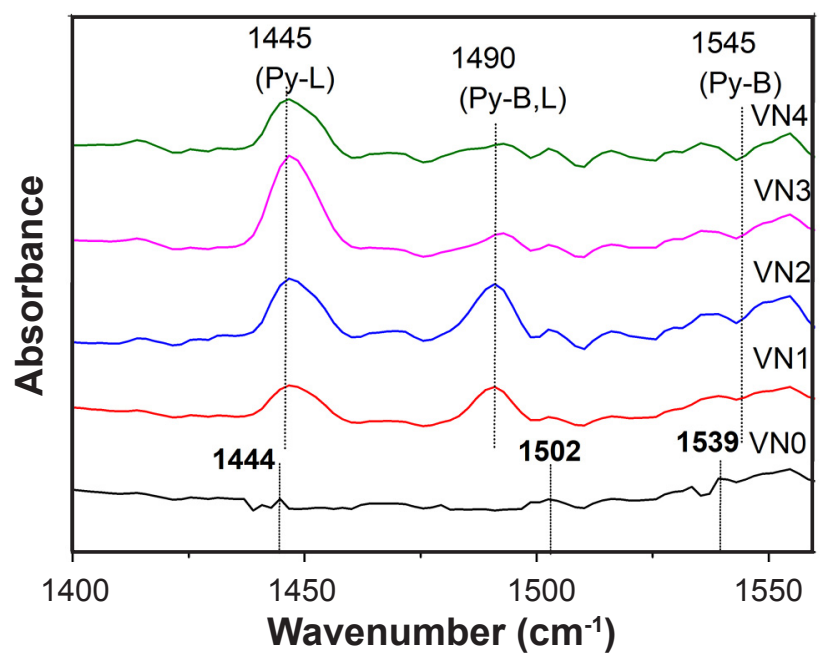

Figure 2: FTIR spectra of the pyridine absorbed from the natural vermiculite-hydrobiotite (VN0) and samples leached with $\mathrm{HNO}_{3}$ (VN1-VN4).

Table II - Lewis acidity data $\left(\mathrm{q}_{\mathrm{L}}, \mu\right.$ mol.g $\left.\mathrm{g}^{-1}\right)$ from vermiculite-hydrobiotite samples leached with $\mathrm{HNO}_{3}$ at $0.25 \mathrm{~mol} . \mathrm{L}^{-1}$ (VN1), $0.50 \mathrm{~mol} . \mathrm{L}^{-1}$ (VN2), $0.75 \mathrm{~mol} . \mathrm{L}^{-1}$ (VN3) and 1.0 mol... $\mathrm{L}^{-1}(\mathrm{VN} 4)$.

\begin{tabular}{cccc}
\hline VN1 & VN2 & VN3 & VN4 \\
\hline 307.6 & 747.2 & 662.8 & 331.4 \\
\hline
\end{tabular}




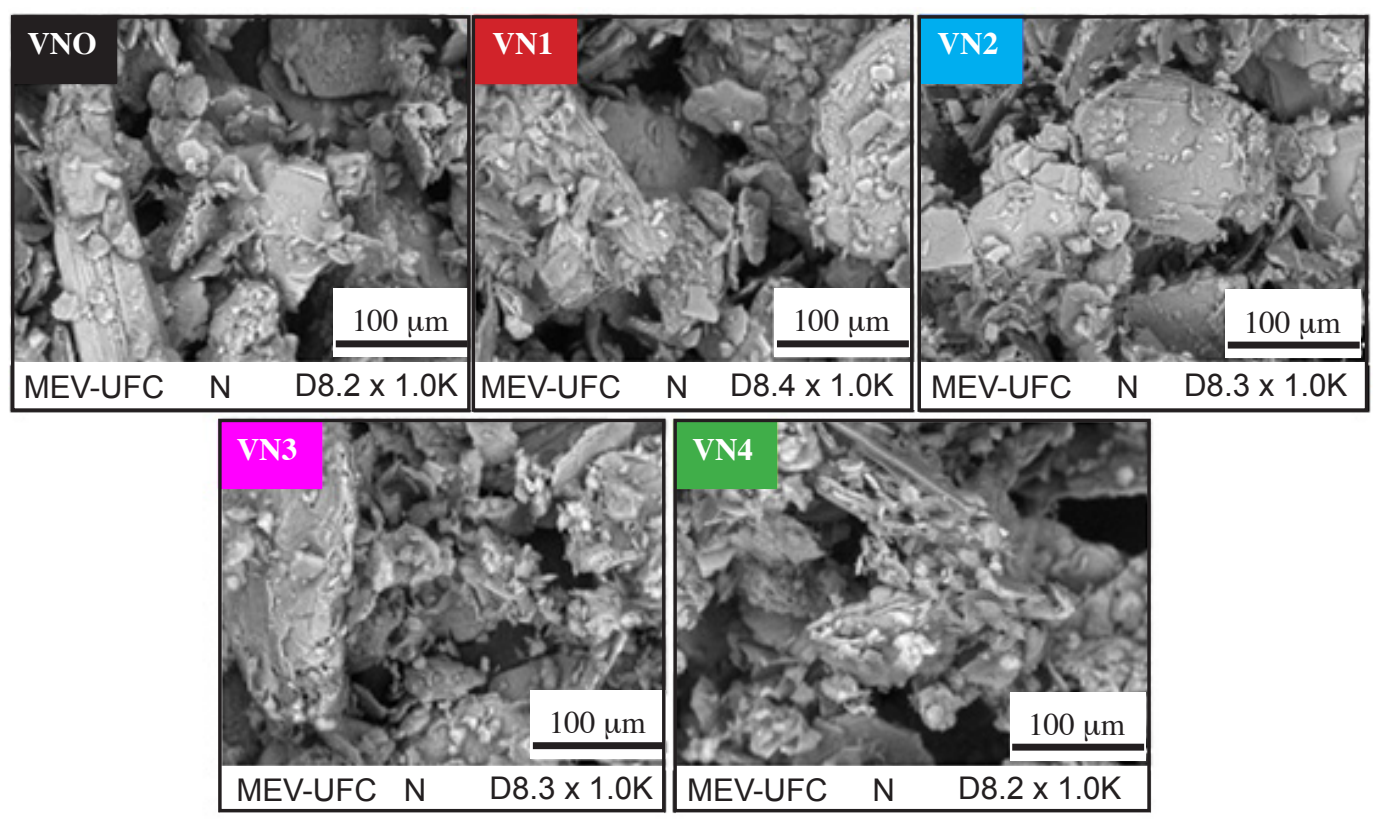

Figure 3: SEM micrographs of natural vermiculite-hydrobiotite (VN0) and samples leached with $\mathrm{HNO}_{3}(\mathrm{VN} 1-\mathrm{VN} 4)$.

acids. In the FTIR spectra of the samples after leaching with $\mathrm{HNO}_{3}$ (Fig. 2), new bands appeared corresponding to the interaction of pyridine with the Lewis acid sites (Py-L) at $1445 \mathrm{~cm}^{-1}$ and the vibrational mode observed at $1490 \mathrm{~cm}^{-1}$ (Py-B,L) concerning the interaction of pyridine with the two acid sites of Brønsted and Lewis. However, the band relative to the interaction of pyridine with Brønsted acid sites (Py-B) was not evidenced. Due to the association of Lewis acidity with the formation of catalysts, they are emphasized in the
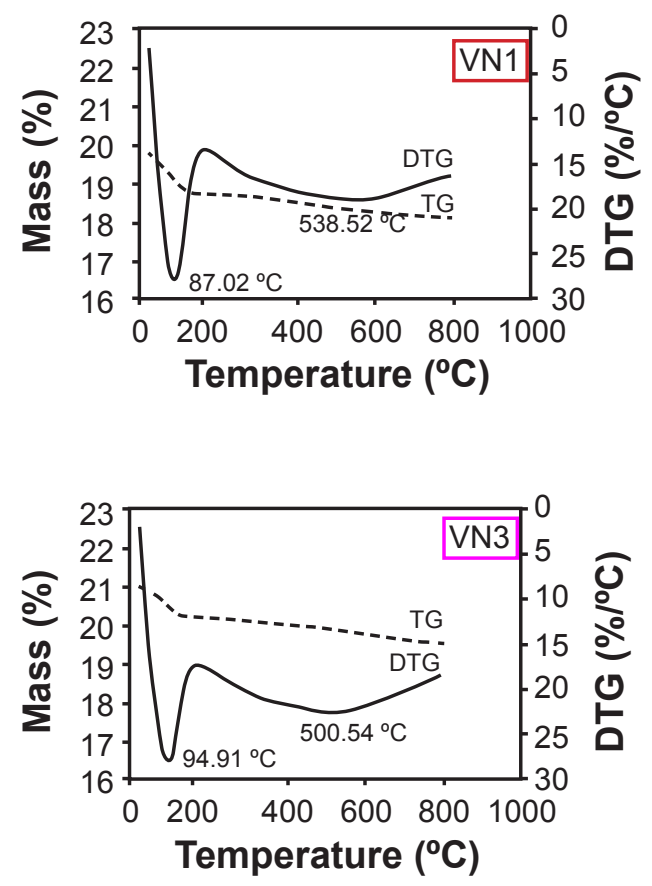

intensities related to that site [32]. The treatment with acid allows the opening of the leaves, consequently, the increase in the exposure of the acidic sites and the decompensation of the charge generated in the isomorphic substitution, which facilitates the deprotection of positive charges allowing the acceptance of electron pairs (Lewis acidity), potentiating Lewis acidity in vermiculite [33]. Table II shows the Lewis acidity values for samples leached with acid $\left(\mathrm{HNO}_{3}\right)$ at different concentrations.
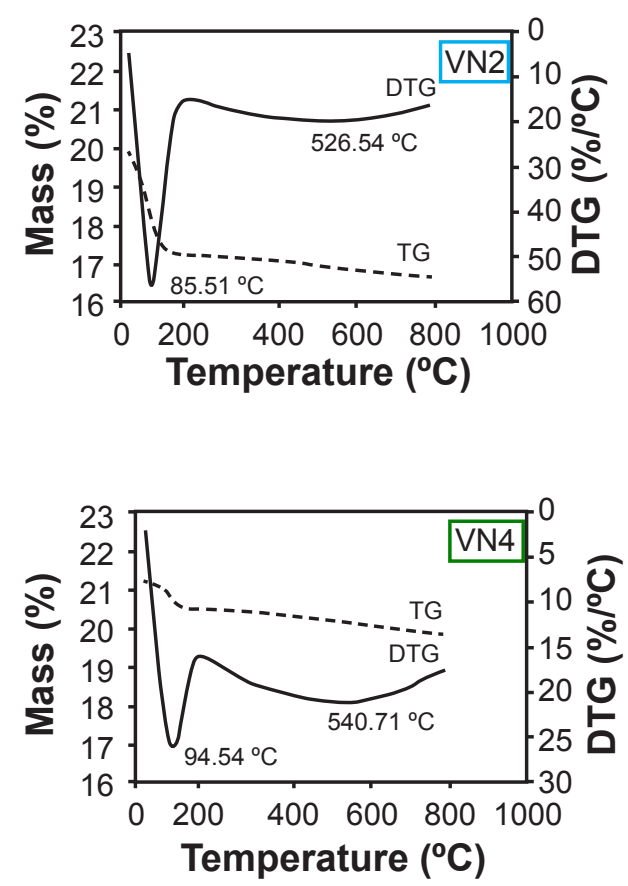

Figure 4: TG and DTG curves of vermiculite-hydrobiotite samples leached with $\mathrm{HNO}_{3}(\mathrm{VN} 1-\mathrm{VN} 4)$. Atmosphere: $\mathrm{N}_{2}$; flow rate: 100 $\mathrm{mL} \cdot \mathrm{min}^{-1}$; heating rate: $10^{\circ} \mathrm{C} \cdot \mathrm{min}^{-1}$. 

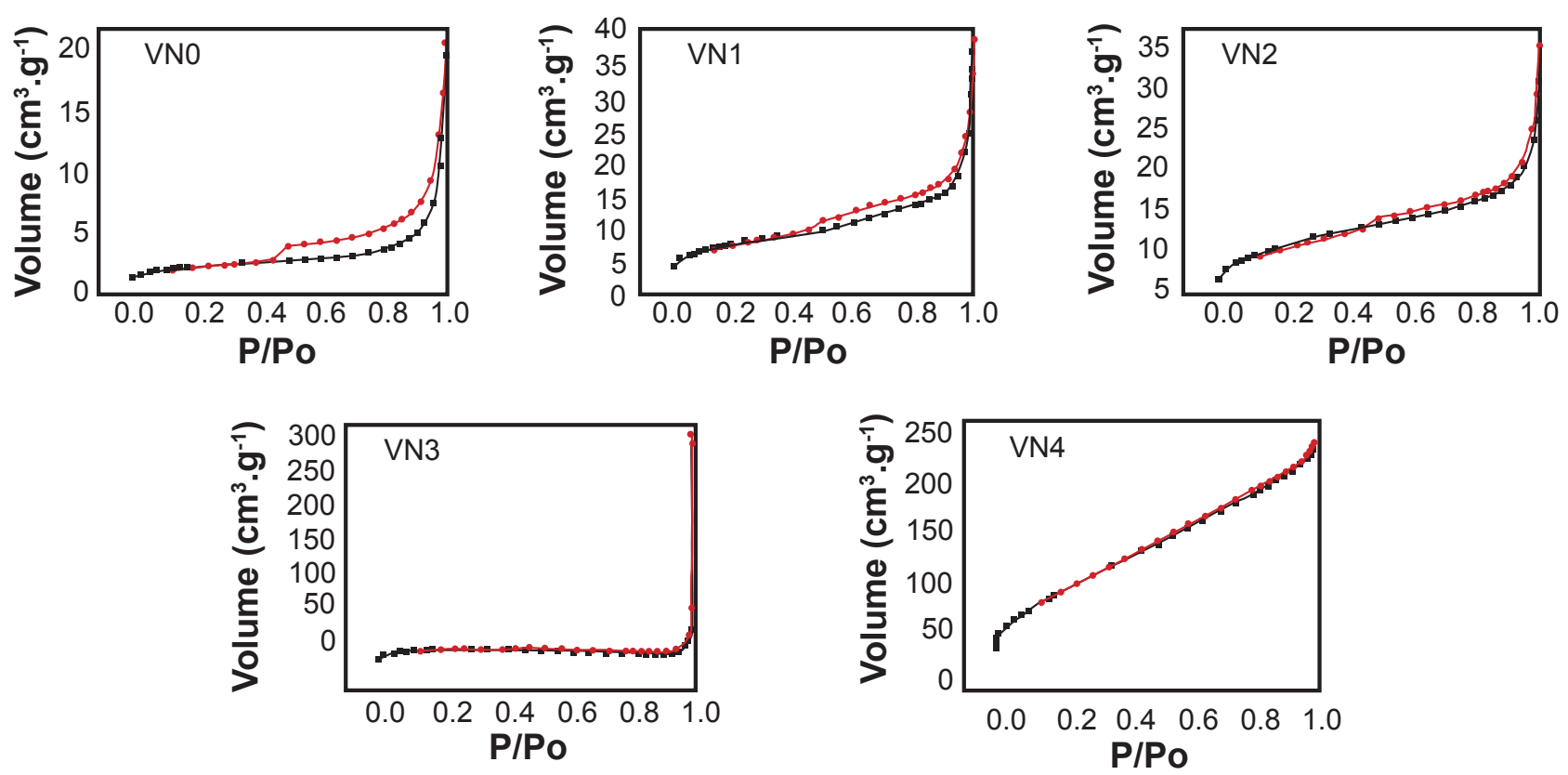

Figure 5: $\mathrm{N}_{2}$ adsorption/desorption isotherms at $77 \mathrm{~K}$ of natural vermiculite-hydrobiotite (VN0) and samples leached with $\mathrm{HNO}_{3}$ (VN1-VN4).

SEM: SEM images of the natural vermiculitehydrobiotite and after leaching are shown in Fig. 3. In the morphology referring to the natural vermiculite (VN0), plaques referring to the silicate layers were observed [34]. After leaching with $\mathrm{HNO}_{3}$ from a concentration of 0.25 mol.L-1 (VN1) to 0.50 mol.L-1 $(\mathrm{VN} 2)$, a characteristic vermiculite-hydrobiotite structure was still observed, however, there was a relative decrease in the size of the attributed particles with the increase in surface area. In the samples treated with higher acid concentrations, VN3 and VN4, the layers were irregularly shaped and the particles were agglomerated, showing structural modification by the vermiculite amorphization process.

$T G$ : TG and DTG (derivative thermogravimetry) curves for the leached vermiculite samples showed two distinct events (Fig. 4). The $1^{\text {st }}$ peak, the most accentuated, occurred between 20 and $100{ }^{\circ} \mathrm{C}$ and referred to the elimination of surface water and water for hydration of cations in the interlayer space. The $2^{\text {nd }}$ event occurred in the range between 500 and $550{ }^{\circ} \mathrm{C}$, which can be attributed to structural water coordinated with the cations present in the interlayer space and also to the clay dehydroxylation process [35].

Table III - Textural properties obtained by adsorption/desorption of $\mathrm{N}_{2}$ from natural vermiculite-hydrobiotite (VN0) and samples leached with $\mathrm{HNO}_{3}$ at $0.25 \mathrm{~mol} . \mathrm{L}^{-1}$ (VN1), 0.50 mol.L ${ }^{-1}$ (VN2), $0.75 \mathrm{~mol} . \mathrm{L}^{-1}(\mathrm{VN} 3)$, and $1.0 \mathrm{~mol} . \mathrm{L}^{-1}(\mathrm{VN} 4)$.

\begin{tabular}{cccc}
\hline Sample & $\mathrm{S}_{\mathrm{BET}}\left(\mathrm{m}^{2} \cdot \mathrm{g}^{-1}\right)$ & $\mathrm{V}_{\mathrm{u}}\left(\mathrm{cm}^{3} \cdot \mathrm{g}^{-1}\right)$ & $\mathrm{R}_{\mathrm{p}}(\mathrm{nm})$ \\
\hline VN0 & 7.8 & 0.029 & 11.8 \\
VN1 & 26 & 0.061 & 5.9 \\
VN2 & 33 & 0.050 & 4.4 \\
VN3 & 98 & 0.072 & 3.1 \\
VN4 & 131 & 0.109 & 2.1 \\
\hline
\end{tabular}

The increase in water content is proportional to the acid concentration, considering that the surface must become more hydrophilic with the presence of more silanol groups, even occurring when hydrated cations leave the interlamellar space and $\mathrm{H}_{3} \mathrm{O}^{+}$cations enter. This fact was observed in the first stage of the TG curves where there was a variation in temperature.

Adsorption/desorption isotherms: the adsorptiondesorption isotherms of natural and leached vermiculitehydrobiotite are shown in Fig. 5. Natural vermiculite had a type II isotherm, characteristic of non-porous or macroporous materials, with a partial pressure of $\mathrm{P} / \mathrm{P}_{0}$ value of around 0.45 , classified as H3 type hysteresis, showing the presence of mesopores [36]. In the leached samples, changes in the curves were observed as the acid concentration increased, obtaining a profile referring to the type I isotherm attributed to microporous solids [25]. An increase in the concentration of acid resulted in a decrease in hysteresis. This effect may be related to the lower amount of mesopores. The textural properties were determined from the isotherms, which showed significant increases of the specific surface area and the volume of pores of the leached samples, changing, respectively, from $7.8 \mathrm{~m}^{2} \cdot \mathrm{g}^{-1}$ and $0.029 \mathrm{~cm}^{3} \cdot \mathrm{g}^{-1}$ in natural vermiculite to $131 \mathrm{~m}^{2} \cdot \mathrm{g}^{-1}$ and $0.109 \mathrm{~cm}^{3} \cdot \mathrm{g}^{-1}$ in the activated vermiculites. These data indicated the efficiency of acid treatment for the production of materials with greater adsorptive power (Table III). The increase in the specific surface area showed that the delamination process occurred, which contributed to generate access to acidic sites, and, at the same time, contributed to the adsorption of molecules [34].

\section{CONCLUSIONS}

In this study, treatment with nitric acid at different concentrations markedly modified the composition, texture, 
and structure of vermiculite, resulting in the formation of promising material for future applications in catalysis and adsorption. In this sense, acid treatment of vermiculitehydrobiotite caused leaching of cations from octahedral leaves, increasing the surface area compared to natural vermiculite. Considerations related to the active sites on the FTIR spectrum indicated greater efficiency in the production of Lewis acid sites when treated with acid $\left(\mathrm{HNO}_{3}\right)$ at 0.75 mol. $\mathrm{L}^{-1}$. However, the X-ray diffractogram showed structural changes and less crystallinity. Thus, leaching was an effective method in the process of chemical modification of vermiculite-hydrobiotite for adsorption purposes, although specific concentrations of acid are necessary, since, as noted, high concentrations can cause structural destruction of the material.

\section{ACKNOWLEDGMENTS}

The authors would like to thank the Laboratory for Research, Development and Innovation in NonMetallic Minerals, the National Council for Scientific and Technological Development - CNPq for the financial support (N.P. Alexandre), and the Institutional Program for Initiation in Technological Development and Innovation - PIBITI for the scholarship provided. Thanks to Polyclay Nanotech Ltd. for supplying the vermiculite sample.

\section{REFERENCES}

[1] O. Duman, S. Tunc, Sep. Sci. Technol. 43, 14 (2008) 3776.

[2] A. Węgrzyn, W. Stawiński, O. Freitas, K. Komędera, A. Błachowski, Ł. Jęczmionek, S. Figueiredo, Appl. Clay Sci. 155 (2018) 37.

[3] W. Stawiński, O. Freitas, L. Chmielarz, A. Węgrzyn, K. Komędera, A. Błachowski, S. Figueiredo, Chemosphere 153 (2012) 115.

[4] S. Dultz, J.-H. An, B. Riebe, Appl. Clay Sci. 67 (2012) 125.

[5] W. Wang, A. Wang (Eds.), "Nanomaterials from clay minerals", Elsevier (2019) 415.

[6] L.N.F. de Queiroga, P.K. Soares, M.G. Fonseca, F.J.V.E. de Oliveira, Appl. Clay Sci. 126 (2016) 113.

[7] F. Ali, L. Reinert, J.M. Lévêque, L. Duclaux, F. Muller, S. Saeed, S. Shah, Ultrason. Sonochem. 21,3 (2014) 1002.

[8] Z.M. Şenol, N. Gürsoy, S. Şimşek, A. Özer, N. Karakuş, Int. J. Biol. Macromol. 148 (2020) 635.

[9] R. Motokawa, H. Endo, S. Yokoyama, H. Ogawa, T. Kobayashi, S. Suzuki, T. Yaita, Langmuir 30, 50 (2014) 15127.

[10] J. Addison, Regul. Toxicol. Pharmacol. 21, 3 (1995) 405.

[11] T.A. Saleh, A. Sari, M. Tuzen, J. Mol. Liq. 219 (2016) 937.

[12] S. Liu, P. Wu, M. Chen, L. Yu, C. Kang, N. Zhu, Z.
Dang, Environ. Pollut. 228 (2017) 277.

[13] A.M. Mathieson, G.F. Walker, J. Earth Planet. Mater. 39, 3-4 (1954) 231.

[14] H. Vali, R. Hesse, Clay Miner. 27, 2 (1992) 192.

[15] L. Dzene, E. Ferrage, F. Hubert, A. Delville, E. Tertre, Appl. Clay Sci. 132 (2016) 215.

[16] L. Ma, X. Su, Y. Xi, J. Wei, X. Liang, J. Zhu, H. He, Appl. Clay Sci. 183 (2019) 105332.

[17] J. Dan, X. Huang, P. Li, Y. Zhang, M. Zhu, X. Guo, F. Yu, Nanosci. Nanotechnol. Lett. 8, 11 (2016) 1028.

[18] L. Wang, X. Wang, J. Yin, C. Wang, Appl. Clay Sci. 132 (2016) 17.

[19] M. Marosz, A. Kowalczyk, L. Chmielarz, Catal. Today 355 (2019) 466.

[20] D.S. Moraes, E.M. Rodrigues, C.N. Lamarão, G.T. Marques, A.F. Rente, J. Hazard. Mater. 366 (2019) 34.

[21] F.J. del Rey-Perez-Caballero, G. Poncelet, Microporous Mesoporous Mater. 37, 3 (2000) 313.

[22] M.M. Chambi-Peralta, A.C.V. Coelho, F.M. de Souza Carvalho, S.M. Toffoli, Appl. Clay Sci. 155 (2018) 2.

[23] Y. Liu, Z. He, L. Zhou, Z. Hou, W. Eli, Catal. Commun. 42 (2013) 44.

[24] S. Aomine, N. Miyauchi, Soil Sci. Plant Nutr. 8, 5 (1962) 22.

[25] S.S.G. Santos, H.R.M. Silva, A.G. de Souza, A.P.M. Alves, E.C. da Silva Filho, M.G. Fonseca, Appl. Clay Sci. 104 (2015) 287.

[26] J. Feng, M. Liu, L. Fu, S. Ma, J. Yang, W. Mo, X. Su, Ceram. Int. 46, 5 (2020) 6413.

[27] M. Valášková, J. Kupková, G.S. Martynková, J. Seidlerová, V. Tomášek, M. Ritz, D. Rafaja, Appl. Clay Sci. 151 (2018) 164.

[28] V. Matějka, M. Šupová, V. Klemm, D. Rafaja, M. Valášková, J. Tokarský, E. Plevová, Microporous Mesoporous Mater. 129, 1-2 (2010) 125.

[29] R.A. Rojas-Ramírez, M.H. Maciel, R.C. de Oliveira Romano, R.G. Pileggi, A.C.V. Coelho, Appl. Clay Sci. 170 (2019) 97.

[30] J. Ravichandran, C.M. Lakshmanan, B. Sivasankar, React. Kinet. Catal. Lett. 59, 2 (1996) 301.

[31] M.E. Gyftopoulou, M. Millan, A.V. Bridgwater, D. Dugwell, R. Kandiyoti, J.A. Hriljac, Appl. Catal. A Gen. 282, 1-2 (2005) 205.

[32] S.I. Okada, K. Tanaka, Y. Nakadaira, N. Nakagawa, Bull. Chem. Soc. Jpn. 65, 10 (1992) 2833.

[33] J. Amaya, L. Bobadilla, L. Azancot, M. Centeno, S. Moreno, R. Molina, J. Mater. Sci. 55, 15 (2020) 6482.

[34] H. Shoukry, M.F. Kotkata, S.A. Abo-El-Enein, M.S. Morsy, S.S. Shebl, Constr. Build. Mater. 112 (2016) 276.

[35] J. Kupková, D. Honěk, S. Vallová, M. Valášková, Acta Geodyn. Geomater. 12, 3 (2015) 299.

[36] S.J. Gregg, K.S.W. Sing, Adsorption, surface area and porosity, $2^{\text {nd }}$ ed., Academic Press, London (1982).

(Rec. 09/07/2020, Rev. 27/08/2020, 25/10/2020, Ac. 06/12/2020) 